\title{
DNA methylation based testing of 450 patients suspected of having Prader-Willi syndrome
}

\author{
Gabriele Gillessen-Kaesbach, Stefanie Gross, Sabine Kaya-Westerloh, \\ Eberhard Passarge, Bernhard Horsthemke
}

\begin{abstract}
Using a test based on parent of origin specific DNA methylation at the D15S63 (PW71) locus, we studied 385 patients (aged 1 to 36 years) for diagnostic confirmation of Prader-Willi syndrome (PWS) and 65 infants (aged 0 to 12 months) with severe hypotonia of unknown cause. Fifty eight of 385 patients were examined personally; 28/58 patients had PWS and lacked the paternal PW71 band and 30/58 patients, who did not have PWS, had a normal methylation pattern. In five of these patients, a differential diagnosis was made (Ohdo-like blepharophimosis syndrome, Alstrøm syndrome, Cohen syndrome, Bardet-Biedl syndrome, and pseudohypoparathyroidism). A total of $327 / 385$ blood samples was sent to us from outside. The test confirmed the diagnosis of PWS in 112/327 patients. Most of the other 215 patients lacked the major diagnostic criteria such as neonatal hypotonia, feeding problems, characteristic facies, and hypogenitalism. On the other hand, 29/65 hypotonic infants tested positive for PWS. We conclude that the PW71 methylation test detects most, if not all, patients with typical PWS and that PWS is often not recognised in infants and wrongly suspected in obese and mentally retarded patients.
\end{abstract}

( $(\mathcal{H}$ Med Genet 1995;32:88-92)

Prader-Willi syndrome (PWS) is a neurogenetic disorder which is characterised by hypotonia and feeding problems in early infancy, hypogenitalism, hyperphagia and obesity, short stature, characteristic facies, behavioural problems, and mental retardation. PWS results from a paternally derived deletion of $15 q 11-13,{ }^{12} \mathrm{ma}-$ ternal uniparental disomy, ${ }^{3-5}$ or an imprinting mutation. ${ }^{67}$ These observations suggest that the PWS genes are subject to parental imprinting. The mechanisms underlying this process are unknown, but most likely involve DNA methylation. This notion is substantiated by the finding of parent of origin specific DNA methylation at three loci within 15q11-13: the zinc finger gene $\mathrm{ZNF} 127,{ }^{8}$ the anonymous marker PW71 (D15S63), ${ }^{9}$ and the gene for the small nuclear ribonucleoprotein N (SNRPN). ${ }^{10}$ At the D15S63 locus, at least one HpaII site and one $C f o I$ site are methylated on the maternal chromosome, but unmethylated on the paternal chromosome. ${ }^{911}$ Based on these differences, we have devised a simple diagnostic test for PWS. Genomic DNA is digested with $H i n d \mathrm{III}+H p a \mathrm{II}$ or $B g l \mathrm{II}+C f o \mathrm{I}$ and hybridised with PW71. Patients with PWS typically lack the paternal PW71 band. ${ }^{12}$ The test detects deletions, uniparental disomies, and imprinting mutations, but does not distinguish between these aberrations. ${ }^{679}$ Here we describe the results obtained in 450 patients suspected of having Prader-Willi syndrome.

\section{Patients and methods}

PATIENTS

From 1 June 1992 to 31 May 1994, we studied 450 patients ( 256 females and 194 males). The ages ranged from 0 to 36 years. A total of $58 /$ 450 patients was examined personally by GG-K and EP using the well defined diagnostic criteria for PWS ${ }^{12}$ and 392 blood samples were sent to us from outside. Referring clinicians were asked to enter the clinical, historical, and anthropometric data into a questionnaire, which was developed by us and sent to all departments of human genetics and paediatrics in Germany.

\section{METHODS}

DNA samples obtained between June 1992 and July $1993(n=265)$ were digested with Hind III + HpaII and hybridised with PW7 $1^{9}$ or PW71B. ${ }^{11}$ Samples obtained between August 1993 and May $1994(n=185)$ were digested with $B g l \mathrm{II}+C f o \mathrm{I}$ and hybridised with PW71B. ${ }^{711}$ Molecular classification was based on the following DNA polymorphisms (restriction enzymes in parentheses): D15S9 (ScaI), D15S11 (RsaI, StyI), D15S13 (TaqI), D15S10 (TaqI), GABRB3 (MspI, XbaI), D15S12 (ScaI), and D15S86 (HinfI). ${ }^{13}$

Results

Using the PW71 methylation test, we studied DNA samples from 450 patients (fig 1). A total 


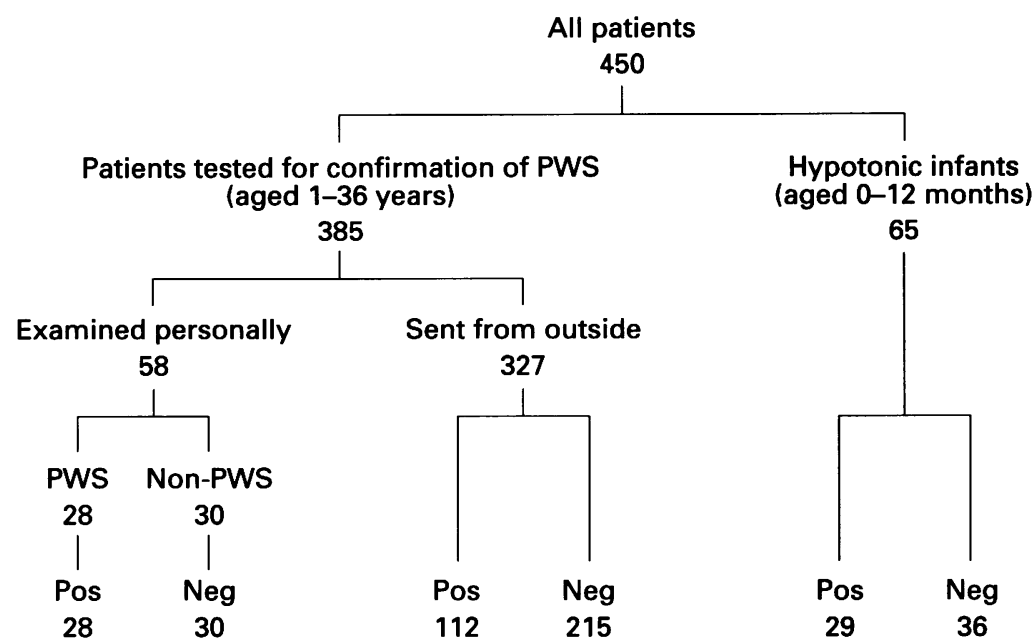

Figure 1 Overview of patients and test results.

of 385/450 patients (aged 1 to 36 years) were tested for confirmation of PWS and 58 of these were examined personally by two of us (GG-K and EP). Sixty five of 450 patients (aged 0 to 12 months) were tested, because they had severe hypotonia of unknown cause.

\section{CLINICAL AND MOLECULAR ANALYSIS OF 58 PATIENTS EXAMINED PERSONALLY}

Twenty nine of 58 patients examined personally fulfilled the diagnostic criteria for PWS as established by Holm et al ${ }^{12}$ (table 1) and 28 of these patients lacked the paternal PW71 band. In 10 cases, parental blood samples were available and informative for DNA polymorphisms on 15q. Eight patients had a deletion and two patients had a maternal isodisomy.

One patient (M3961) had a normal methylation pattern. Although he fulfils the diagnostic criteria of Holm et $a l^{12}$ (table 2), he does not have PWS, but "Ohdo-like blepharophimosis syndrome with distinctive facies, neonatal hypotonia, mental retardation, and hypoplastic teeth". The patient was born after an uneventful pregnancy. The birth weight was $3750 \mathrm{~g}$, length $54 \mathrm{~cm}$, and head circumference $37 \mathrm{~cm}$. He showed severe hypotonia, feeding problems, and scrotal hypoplasia, a wide, depressed nasal bridge, hypoplastic teeth, and micrognathia (fig 2). He had an inner canthal distance (ICD) of $3.0 \mathrm{~cm}$ (97th centile) and a palpebral fissure length of $2.0 \mathrm{~cm}(-2 \mathrm{SD})$. His height was $80 \mathrm{~cm}(97 \mathrm{th}$ centile) and his weight was $12 \mathrm{~kg}$ (90th to 97 th centile). His developmental milestones were delayed. Cytogenetic analysis showed a normal male karyotype $(46, \mathrm{XY})$ at the 850 band level.

Twenty-nine of 58 patients did not fulfil the diagnostic criteria and had a normal methylation pattern (table 2). In six cases, parental blood samples were available and biparental inheritance was shown. In four patients, another diagnosis could be made. Patient M1871 is the only child of a consanguineous Turkish couple. There was no history of neonatal hypotonia or feeding problems. When he was 8 months old, the parents noticed nystagmus and photophobia. We examined the boy at the age of 3 years 6 months. Developmental milestones were delayed. Walking unaided started at 18 months. Obesity developed in his second year of life. His height was $101.6 \mathrm{~cm}$ (50th centile) and his weight was $29 \mathrm{~kg}(20 \mathrm{~kg}$ above the 90th centile). Examination of the eyes showed retinitis pigmentosa. Brain stem audiometry did not indicate retrocochlear lesions. Physical examination showed no abnormalities except nystagmus and severe obesity. The most likely diagnosis in this boy is Alstrøm syndrome (MIM 203800), a condition consisting of retinitis pigmentosa, deafness, and diabetes mellitus. The disorder bears some similarities to

Table 1 Clinical and molecular data of personally examined patients with PWS

\begin{tabular}{|c|c|c|c|c|c|c|c|c|c|c|c|c|c|c|}
\hline Patient & Sex & $\begin{array}{l}\text { Age at } \\
\text { clinical } \\
\text { examin }\end{array}$ & ation & $\begin{array}{l}\text { Hypo- } \\
\text { tonia }\end{array}$ & $\begin{array}{l}\text { Feeding } \\
\text { problems }\end{array}$ & $\begin{array}{l}\text { Character- } \\
\text { istic facies }\end{array}$ & $\begin{array}{l}\text { Hypo- } \\
\text { genitalism }\end{array}$ & $\begin{array}{l}\text { Hyper- } \\
\text { phagia }\end{array}$ & $\begin{array}{l}\text { Obesity } \\
\text { after } 1 y\end{array}$ & $\begin{array}{l}\text { Global } \\
\text { delay/ } \\
\text { mental } \\
\text { retardation }\end{array}$ & $\begin{array}{l}\text { Short } \\
\text { stature }\end{array}$ & $\begin{array}{l}\text { Behavioral } \\
\text { problems }\end{array}$ & $\begin{array}{l}\text { Molecular } \\
\text { classification }\end{array}$ & $\begin{array}{l}\text { PW71 } \\
\text { test }\end{array}$ \\
\hline G0831 & $\mathbf{M}$ & $36 y$ & & + & + & + & + & + & + & + & + & + & Deletion & Positive \\
\hline G1034 & $\mathbf{M}$ & $6 y$ & $4 m$ & + & + & + & + & + & + & + & + & - & Isodisomy & Positive \\
\hline G1157 & M & $5 y$ & $6 \mathrm{~m}$ & + & + & + & + & + & + & + & + & + & ND & Positive \\
\hline G1189 & $\mathbf{M}$ & $1 y$ & $6 \mathrm{~m}$ & + & + & + & + & + & + & + & - & + & Deletion & Positive \\
\hline G1394 & $\mathbf{F}$ & $16 y$ & $6 \mathrm{~m}$ & + & + & + & + & + & + & + & + & + & Deletion & Positive \\
\hline G1442 & $\mathbf{F}$ & $1 y$ & $8 \mathrm{~m}$ & + & + & + & + & + & + & + & + & + & Deletion* & Positive \\
\hline G1486 & $\mathbf{F}$ & $8 y$ & $5 \mathrm{~m}$ & + & + & + & + & + & + & + & + & + & Deletion & Positive \\
\hline M0031 & M & $16 y$ & $5 \mathrm{~m}$ & + & + & + & + & + & + & + & + & + & Deletion & Positive \\
\hline M0047 & M & $5 y$ & $2 \mathrm{~m}$ & + & + & + & + & + & + & + & + & + & Isodisomy & Positive \\
\hline M0049 & $\mathrm{F}$ & $12 y$ & $1 \mathrm{~m}$ & + & + & + & + & + & + & + & + & + & Deletion & Positive \\
\hline M0052 & $\mathbf{F}$ & $11 \mathrm{y}$ & $5 \mathrm{~m}$ & + & + & + & + & + & + & + & + & + & Deletion & Positive \\
\hline M0320 & $\mathrm{F}$ & $25 y$ & $10 \mathrm{~m}$ & + & + & + & + & + & + & $(+)$ & + & + & ND & Positive \\
\hline M0818 & $\mathbf{M}$ & $2 y$ & $2 m$ & + & - & + & + & - & - & + & + & - & ND & Positive \\
\hline M0820 & $\mathbf{M}$ & $7 y$ & & + & + & + & + & + & + & - & + & + & ND & Positive \\
\hline M0984 & $\mathbf{M}$ & $18 y$ & & + & + & + & + & + & + & + & + & + & ND & Positive \\
\hline M1452 & $\mathbf{F}$ & $4 y$ & $11 \mathrm{~m}$ & + & + & + & + & + & + & + & + & + & ND & Positive \\
\hline M1740 & $\mathbf{F}$ & $2 y$ & $1 \mathrm{~m}$ & + & + & + & + & - & - & + & - & $(+)$ & ND & Positive \\
\hline M2032 & $\mathrm{F}$ & $5 y$ & $1 \mathrm{~m}$ & + & + & + & + & + & + & + & - & + & ND & Positive \\
\hline M2150 & $\mathbf{M}$ & $4 y$ & $6 \mathrm{~m}$ & + & + & + & + & + & + & + & - & + & ND & Positive \\
\hline M2303 & M & $3 y$ & $3 \mathrm{~m}$ & + & + & + & + & + & + & + & + & + & ND & Positive \\
\hline M2324 & $\mathrm{F}$ & $1 y$ & $3 \mathrm{~m}$ & + & + & + & + & - & + & + & + & - & ND & Positive \\
\hline M2429 & $\mathbf{M}$ & $10 \mathrm{y}$ & $11 \mathrm{~m}$ & + & + & + & + & + & + & + & - & + & ND & Positive \\
\hline M2692 & $\mathbf{M}$ & $33 y$ & & + & + & + & + & + & + & + & + & + & ND & Positive \\
\hline M3351 & $\mathbf{M}$ & $15 y$ & $6 \mathrm{~m}$ & + & + & + & + & + & + & $(+)$ & - & + & ND & Positive \\
\hline M3397 & $\mathbf{F}$ & $4 y$ & $3 \mathrm{~m}$ & + & + & + & + & + & + & + & + & + & ND & Positive \\
\hline M3432 & $\mathbf{M}$ & $29 y$ & & + & + & + & + & + & + & + & + & + & ND & Positive \\
\hline M3781 & $\mathbf{M}$ & $6 y$ & $11 \mathrm{~m}$ & + & + & + & + & + & - & + & + & + & ND & Positive \\
\hline M4045 & $\mathbf{M}$ & $13 y$ & $3 m$ & + & + & + & + & + & + & + & - & + & ND & Positive \\
\hline
\end{tabular}

* Unbalanced translocation $t(X ; 15)$. Abbreviations are as follows: +, present; (+), borderline; -, absent; ND, not determined; Positive, absence of paternal band;

Negative, normal methylation pattern. 


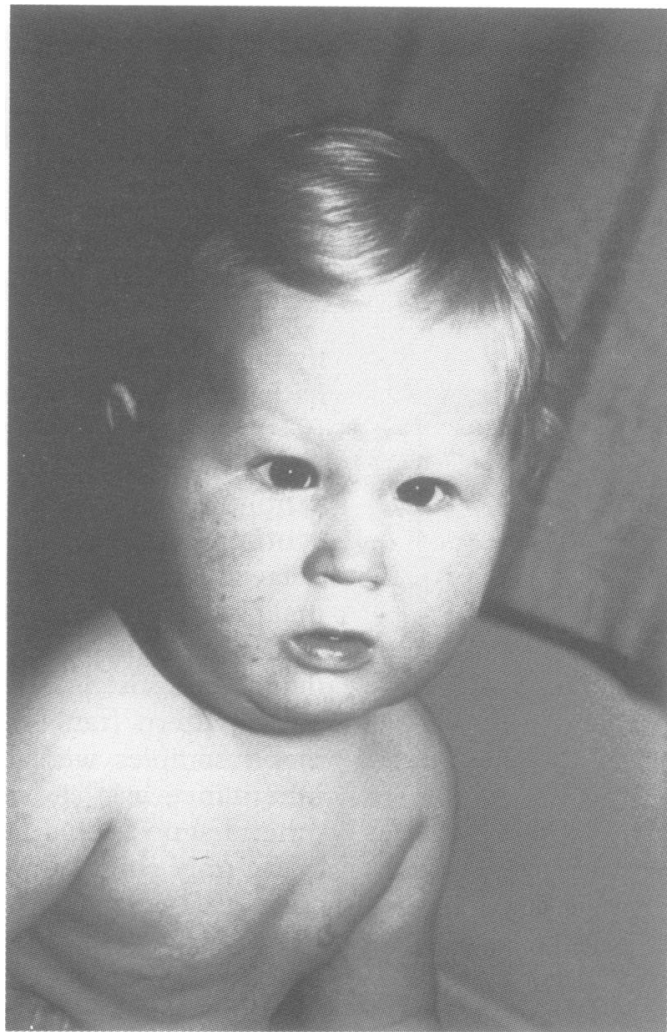

Figure 2 Patient with "Ohdo-like blepharophimosis syndrome with distinctive facies, neonatal hypotonia, mental retardation, and hypoplastic teeth".

the Bardet-Biedl syndrome, but can be differentiated by the lack of polydactyly, short stature, and hypogonadism.

Patient M2165 was referred for diagnostic evaluation at the age of 14 years because of short stature, obesity, and mental retardation. He was born to healthy, non-consanguineous parents. Birth weight was $2750 \mathrm{~g}$ and length $48 \mathrm{~cm}$. At the age of 14 years 10 months his height was $150 \mathrm{~cm}$ ( $3 \mathrm{rd}$ centile) and his weight was $50 \mathrm{~kg}$ (above the 90th centile). Physical examination showed an open mouth, prominent upper incisors, and a short philtrum. The palpebral fissures were downward slanted. He showed truncal obesity and no signs of puberty. Endocrinological evaluation indicated low testosterone levels. Eye examination was normal. A male karyotype $(46, \mathrm{XY})$ was found. A diagnosis of Cohen syndrome (MIM 216550) was based on the following findings: mental retardation, short stature, hypogonadism, short philtrum, open mouth, and prominent upper incisors.

Patient M0140 was 12 years old when referred to our department with the tentative diagnosis of Prader-Willi syndrome. The diagnosis was suspected because of obesity, muscular hypotonia, and mental retardation. Evaluation of the medical records of the boy indicated the diagnosis of pseudohypoparathyroidism (MIM 103580). The following findings were in favour of this diagnosis: hypothyroidism, hypocalcaemia, seizures, intracerebral calcifications, frontal bossing, midfacial hypoplasia, and shortening of all metacarpals and of the third and fourth metatarsals.

Patient M2624 was referred to us from our paediatric department. Since birth, an obstructive uropathy with consequent renal insufficiency had been documented. Prader-Willi syndrome was suspected because of muscular hypotonia, developmental delay, obesity, and cryptorchidism. Cytogenetic analysis showed a normal male karyotype $(46, \mathrm{XY})$. We examined the boy for the first time at the age of 6 years 6 months and made the diagnosis of BardetBiedl syndrome (MIM 209900) because of the findings of bilateral hexadactyly, obesity, and short stature. A follow up examination of the eyes showed retinitis pigmentosa, a typical finding in Bardet-Biedl syndrome.

Table 2 Clinical and molecular data of personally examined patients who do not have PWS

\begin{tabular}{|c|c|c|c|c|c|c|c|c|c|c|c|c|c|c|}
\hline Patient & Sex & $\begin{array}{l}\text { Age at } \\
\text { clinical } \\
\text { examina }\end{array}$ & ation & $\begin{array}{l}\text { Hypo- } \\
\text { tonia }\end{array}$ & $\begin{array}{l}\text { Feeding } \\
\text { problems }\end{array}$ & $\begin{array}{l}\text { Character- } \\
\text { istic facies }\end{array}$ & $\begin{array}{l}\text { Hypo- } \\
\text { genitalism }\end{array}$ & $\begin{array}{l}\text { Hyper- } \\
\text { phagia }\end{array}$ & $\begin{array}{l}\text { Obesity } \\
\text { after } \\
1 y\end{array}$ & $\begin{array}{l}\text { Global } \\
\text { delay/ } \\
\text { mental } \\
\text { retardation }\end{array}$ & $\begin{array}{l}\text { Short } \\
\text { stature }\end{array}$ & $\begin{array}{l}\text { Behavioural } \\
\text { problems }\end{array}$ & $\begin{array}{l}\text { Molecular } \\
\text { classification }\end{array}$ & $\begin{array}{l}\text { PW71 } \\
\text { test }\end{array}$ \\
\hline G1418 & $\mathbf{M}$ & $9 \mathrm{y}$ & $4 \mathrm{~m}$ & + & - & - & - & + & + & + & - & - & Normal & Negative \\
\hline G1491 & $\mathbf{M}$ & $3 y$ & $6 \mathrm{~m}$ & + & + & - & + & + & + & + & - & - & Normal & Negative \\
\hline G1493 & $\mathrm{F}$ & $23 y$ & $7 \mathrm{~m}$ & - & - & - & - & + & + & + & - & + & Normal & Negative \\
\hline G1506 & $\mathbf{F}$ & $8 \mathrm{y}$ & $9 m$ & - & - & - & - & + & + & + & - & - & Normal & Negative \\
\hline M0140 & $\mathbf{M}$ & $12 \mathrm{y}$ & & + & + & - & - & + & + & + & - & - & Normal & Negative \\
\hline M0418 & $\mathrm{F}$ & $3 y 1$ & $10 \mathrm{~m}$ & - & - & - & - & - & - & $(+)$ & - & - & Normal & Negative \\
\hline M1084 & F & $2 y$ & $5 \mathrm{~m}$ & ND & + & - & - & - & + & + & - & - & ND & Negative \\
\hline M1175 & $\mathbf{M}$ & $17 \mathrm{y}$ & & - & - & - & - & + & + & + & - & - & ND & Negative \\
\hline M1467 & M & $14 \mathrm{y}$ & $6 \mathrm{~m}$ & - & - & - & - & + & + & - & - & - & ND & Negative \\
\hline M1501 & M & $1 \mathrm{y}$ & $1 \mathrm{~m}$ & - & - & - & - & + & + & - & - & - & ND & Negative \\
\hline M1632 & $\mathrm{F}$ & $11 \mathrm{y}$ & $2 \mathrm{~m}$ & - & - & - & + & + & + & + & - & - & $\mathrm{ND}$ & Negative \\
\hline M1867 & M & $4 y$ & $6 \mathrm{~m}$ & - & - & - & + & + & + & + & - & - & ND & Negative \\
\hline M1871 & $\mathbf{M}$ & $3 y$ & $6 \mathrm{~m}$ & - & - & - & - & + & + & + & - & - & $\mathrm{ND}$ & Negative \\
\hline M1879 & M & $12 \mathrm{y}$ & $8 \mathrm{~m}$ & - & - & - & - & + & + & + & - & - & ND & Negative \\
\hline M1999 & $\mathrm{F}$ & $4 y$ & $4 \mathrm{~m}$ & - & - & - & - & + & + & + & - & - & ND & Negative \\
\hline M2032 & F & ly & $5 \mathrm{~m}$ & - & + & - & - & - & - & - & + & - & ND & Negative \\
\hline M2165 & $\mathbf{M}$ & $14 y$ & & - & - & - & + & + & + & + & + & + & ND & Negative \\
\hline M2444 & F & $4 y$ & $1 \mathrm{~m}$ & + & + & - & - & + & + & - & - & - & ND & Negative \\
\hline M2508 & $\mathrm{F}$ & $14 \mathrm{y}$ & $1 \mathrm{~m}$ & + & - & - & + & + & + & + & - & - & ND & Negative \\
\hline M2522 & $\mathbf{M}$ & $2 \mathrm{y}$ & $9 \mathrm{~m}$ & + & - & - & - & + & + & + & - & - & ND & Negative \\
\hline M2624 & M & $6 y$ & $6 \mathrm{~m}$ & + & - & - & - & + & + & + & + & + & ND & Negative \\
\hline M3007 & $\mathbf{F}$ & $12 \mathrm{y}$ & & + & - & - & - & + & + & $(+)$ & + & - & $\mathrm{ND}$ & Negative \\
\hline M3062 & $\mathbf{F}$ & $3 y$ & & + & + & - & + & - & - & + & + & - & ND & Negative \\
\hline M3189 & $\mathrm{F}$ & $4 y$ & $4 m$ & ND & ND & - & - & + & + & + & - & - & ND & Negative \\
\hline M3304 & $\mathbf{M}$ & 9 y 1 & $1 \mathrm{~m}$ & + & - & - & - & + & + & + & - & - & ND & Negative \\
\hline M3349 & F & $1 \mathrm{y}$ & $7 \mathrm{~m}$ & - & + & - & - & + & + & + & - & - & ND & Negative \\
\hline M3892 & M & $8 \mathrm{y}$ & $9 m$ & - & + & - & - & + & + & + & - & + & ND & Negative \\
\hline M3961* & M & ly & $1 \mathrm{~m}$ & + & + & - & + & + & + & + & - & - & ND & Negative \\
\hline M4247 & $\mathbf{F}$ & ly & $4 \mathrm{~m}$ & + & - & - & - & - & - & - & - & - & ND & Negative \\
\hline M4424 & $\mathbf{M}$ & $13 y$ & $2 \mathrm{~m}$ & + & + & - & - & - & - & + & - & - & ND & Negative \\
\hline
\end{tabular}

* The patient fulfils the diagnostic criteria for PWS, ${ }^{12}$ but has Ohdo-like blepharophimosis syndrome (see text for details). Abbreviations as in table 1 . 
Table 3 Frequency (\%) of clinical findings in the patients from outside

\begin{tabular}{|c|c|c|c|c|c|c|c|c|c|}
\hline Patient group & Hypotonia & $\begin{array}{l}\text { Feeding } \\
\text { problems }\end{array}$ & $\begin{array}{l}\text { Characteristic } \\
\text { facies }\end{array}$ & Hypogenitalism & Hyperphagia & $\begin{array}{l}\text { Obesity } \\
\text { after } \\
1 y\end{array}$ & $\begin{array}{l}\text { Global/delay } \\
\text { mental } \\
\text { retardation }\end{array}$ & $\begin{array}{l}\text { Short } \\
\text { stature }\end{array}$ & $\begin{array}{l}\text { Behavioural } \\
\text { problems }\end{array}$ \\
\hline $\begin{array}{l}\text { PW71 positive } \\
\text { PW71 negative }\end{array}$ & $\begin{array}{l}85 \\
43\end{array}$ & $\begin{array}{l}76 \\
33\end{array}$ & $\begin{array}{l}81 \\
20\end{array}$ & $\begin{array}{l}62 \\
24\end{array}$ & $\begin{array}{l}82 \\
79\end{array}$ & $\begin{array}{l}82 \\
75\end{array}$ & $\begin{array}{l}80 \\
83\end{array}$ & $\begin{array}{l}41 \\
31\end{array}$ & $\begin{array}{l}36 \\
40\end{array}$ \\
\hline
\end{tabular}

Not all questionnaires were complete. The data shown here are based on 92/112 PW71 positive patients and 171/215 PW71 negative patients. Abbreviations as in table 1 .

MOLECULAR ANALYSIS OF 327 BLOOD SAMPLES RECEIVED FROM OUTSIDE

A total of $327 / 385$ blood samples was sent to us from outside for diagnostic confirmation of PWS, together with a questionnaire referring to the clinical, historical, and anthropometric data. Of these 327, 112 patients lacked the paternal PW71 band. This confirmed the diagnosis of PWS in these patients. A total of 215/327 patients had a normal methylation pattern. Most of these patients lacked the major diagnostic criteria ${ }^{12}$ such as neonatal hypotonia, feeding problems, characteristic facies, and hypogenitalism (table 3 ).

MOLECULAR ANALYSIS OF 65 INFANTS WITH SEVERE HYPOTONIA OF UNKNOWN CAUSE Sixty five blood samples from young infants were sent to us, because they had severe hypotonia of unknown cause and 29/65 patients lacked the paternal PW71 band. Based on this result, the diagnosis of PWS was made. Thirty six of 65 patients had a normal methylation pattern.

\section{Discussion}

Although well defined diagnostic criteria have been established, ${ }^{12}$ it is often difficult to make the clinical diagnosis of PWS, especially in the newborn and children under 3 years of age. This problem is highlighted by the patient with Ohdo-like blepharophimosis syndrome. Therefore, a simple molecular test for PWS is needed. We have recently shown that the PW71 methylation test detects all classes of chromosome 15 defects currently known to cause PWS: deletions, uniparental disomies, and imprinting mutations. ${ }^{69}$ This was confirmed by two independent studies ${ }^{1415}$ and again by the analysis of the patients examined personally and described here. The combined data suggest that the PW71 methylation test detects most, if not all, patients with typical PWS and that it is safe to do this test first. It should be noted, however, that the methylation test gives no information about the nature of the genetic defect. If this information is required, for example for determining the recurrence risk, conventional chromosome analysis, fluorescence in situ hybridisation, and DNA polymorphism studies should be added to the diagnostic procedures. Owing to its high rate of false positive and false negative results, high resolution chromosome analysis was not routinely performed in our patients and is not recommended for the diagnosis of PWS.

Over the past two years, we have identified a total of 169 patients with PWS. Assuming an incidence of $1 / 12000$ and an annual birth rate of about 600000 in Germany during the past 36 years, we estimate that we have identified 5 to $10 \%$ of all German PWS patients below the age of 36 years. The high frequency of negative findings in the patients referred to us for personal examination (52\%) and in the samples from outside $(66 \%)$ may reflect the general tendency that more patients are considered for diagnostic testing once an easy test becomes available. We cannot exclude the possibility that the group of PW71 negative patients from outside contains a few PWS patients who have a genetic defect not detectable by PW71, but our findings support the previous impression that PWS is often wrongly suspected in obese and mentally retarded patients. This is also obvious from the data provided by the questionnaires (table 3 ). Although these data could not be verified by personal examination of the patients, they indicate that most of the patients with a normal methylation pattern lack major diagnostic criteria, ${ }^{12}$ such as neonatal hypotonia, feeding problems, characteristic facies, and hypogenitalism.

In some of the patients examined personally we were able to make a differential diagnosis. Our major differential diagnoses included Cohen syndrome, pseudohypoparathyroidism, Alstrøm syndrome, and Bardet-Biedl syndrome. A very interesting differential diagnosis was made in patient M3961. The Ohdo-like blepharophimosis syndrome shows a number of overlapping features with PWS in the neonatal period, such as muscular hypotonia, feeding problems, and scrotal hypoplasia, but the craniofacial abnormalities are clearly distinct. ${ }^{16}$ Less experienced clinicians may not be able to differentiate this condition from PWS by clinical examination alone. We are well aware of the fact that the list of differential diagnoses is far from being complete because it is only based on a small number of patients. Numerous differential diagnoses are possible, expecially in newborns presenting with hypotonia and feeding problems.

Among 65 young infants with severe hypotonia of unknown cause, we have found 29 patients $(45 \%)$ who tested positive for PWS. The high frequency of positive findings in this group of patients was unexpected and is most likely because of ascertainment bias. For accurate assessment of the frequency of PWS among hypotonic newborns, we have started a two year prospective study in which all children born in two large German cities (annual birth rate 6000 ) will be clinically examined, and hypotonic infants will be tested for PWS. Despite the ascertainment bias in our present study, 
PWS is a significant cause of hypotonia in early infancy and we suggest performing the PW71 methylation test in such cases. This may help to prevent more invasive diagnostic procedures and ensure early support for the patient.

We thank Dr K Buiting, B Dittrich, and H Knoblauch for helpful discussions. Part of this work was supported by the Deutsche Forschungsgemeinschaft.

1 Butler MG, Meany FJ, Palmer CG. Clinical and cytogenetic survey of 39 individuals with Prader-Labhart-Willi synsurvey of 39 individuals with Prader-Labhar
drome. Am 7 Med Genet 1986;23:793-809.

2 Knoll JHM, Nicholls RD, Magenis ER, Graham JM Jr, Lalande M. Angelman and Prader-Willi syndromes share a common chromosome 15 deletion but differ in parental origin of the deletion. Am $\mathcal{F}$ Med Genet 1991;32:285-90.

3 Nicholls RD, Knoll JH, Butler MG, Karam S, Lalande M. Genetic imprinting suggested by maternal uniparental heterodisomy in nondeletion Prader-Willi syndrome. $\mathrm{Na}$ ture 1989;342:281-5.

4 Robinson WP, Bottani A, Yagang X, et al. Molecular, cytogenetic, and clinical investigations of Prader-Willi syndrome patients. Am f Hum Genet 1991;49:1219-34.

5 Mascari MJ, Ladda RL, Gottlieb W, et al. Frequency of uniparental disomy in Prader-Willi syndrome. $N$ Engl $\mathcal{f}$ Med 1992;326:1599-607.

6 Reis A, Dittrich B, Greger V, et al. Imprinting mutations suggested by abnormal DNA methylation patterns in fa-
milial Angelman and Prader-Willi syndromes. Am f Hum Genet 1994;54:741-7.
7 Buiting K, Dittrich B, Robinson WP, et al. Detection of aberrant DNA methylation in unique Prader-Willi syndrome patients and its diagnostic implications. Hum Molec Genet 1994;3:893-5.

8 Driscoll DJ, Waters MF, Williams CA, et al. A DNA methylation imprint, determined by the sex of the parent, distinguishes the Angelman and Prader-Willi syndromes. Genomics 1992;13:917-24.

9 Dittrich D, Robinson WP, Knoblauch H, et al. Molecular diagnosis of the Prader-Willi and Angelman syndromes by detection of parent-of-origin specific DNA methylation in 15q11-13. Hum Genet 1992;90:313-15.

10 Glenn CC, Porter KA, Jong MTC, Nicholls RD, Driscoll DJ. Functional imprinting and epigenetic modification of the human SNRPN gene. Hum Molec Genet 1993;2: of the h.

11 Dittrich B, Buiting K, Gross S, Horsthemke B. Characterization of a methylation imprint in the Prader-Will syndrome region. Hum Molec Genet 1993;2:1995-9.

12 Holm VA, Cassidy SB, Butler MG, et al. Prader-Willi syndrome: consensus criteria. Pediatrics 1993;91:398-402.

13 Human Gene Mapping 11 (1991). Cytogenet Cell Genet 1991;58:1517-24.

14 van den Ouweland A, van der Est M, Tijmen T, Wesbyvan Swaay E, Halley D. Use of probe PW71 (D15S63) in DNA diagnostics of Prader-Willi syndrome patients. Am f Hum Genet 1993;53:A1764.

15 Lerer I, Meiner V, Pashut-Lavon I, Abeliovich D. Molecular diagnosis of Prader-Willi syndrome: parent-of-origin dediagnosis of Prader-Which synd pendent hathetion of Genet 1994;52:79-84.

16 Clayton-Smith J, Krajewska-Walasek M, Fryer A, Donnai D. Ohdo-like blepharophimosis syndrome with distinctive facies, neonatal hypotonia, mental retardation and hypoplastic teeth. Clin Dysmorphol 1994;3:115-20. 